\title{
An X-ray diffraction study of corrosion products from low carbon steel
}

\author{
A.L. Morales
}

\begin{abstract}
It was found in earlier work a decrease in the corrosion rate from low carbon steel when it was subjected to the action of a combined pollutant concentration $\left(\mathrm{SO}_{4}{ }^{2-}=10^{-4} \mathrm{M}+\mathrm{Cl}^{-}=1.5 \times 10^{-3} \mathrm{M}\right)$. It was also found that large magnetite content of the rust was related to higher corrosion rates. In the present study corrosion products are further analyzed by means of X-ray diffraction to account for composition changes during the corrosion process. It is found that lepidocrocite and goethite are the dominant components for the short-term corrosion in all batches considered while for log-term corrosion lepidocrite and goethite dominates if the corrosion rate is low and magnetite dominates if the corrosion rate is high. The mechanism for decreasing the corrosion rate is related to the inhibition of magnetite production at this particular concentration.
\end{abstract}

Keywords Corrosion rate. X-ray diffraction. Steel. Mössbauer spectroscopy. Sulfate and chloride ions.

\section{Estudio por difracción de rayos $\mathrm{X}$ de los productos de corrosión del acero al carbono}

Resumen En un estudio anterior se encontró que la tasa de corrosión, de un acero al carbono, decrecía cuando se le sometía al efecto combinado de una mezcla de contaminantes $\left(\mathrm{SO}_{4}{ }^{2-}=10^{-4} \mathrm{M}+\mathrm{Cl}^{-}=1,5 \times 10^{-3} \mathrm{M}\right)$. También, se concluyó que altos contenidos de magnetita en la herrumbre estaban asociados a altas tasas de corrosión. En este trabajo se retoman estas herrumbres para analizarlas por difractometría de rayos X para tomar en cuenta los cambios en composición durante el proceso corrosivo. Se encuentra que goethita y lepidocrocita son las componentes dominantes durante la etapa inicial del proceso en todos los experimentos. En cambio para tiempos largos de exposición, y si la tasa de corrosión es alta, la magnetita es el producto de corrosión dominante. El mecanismo que reduce la tasa de corrosión, en la mezcla mencionada anteriormente, está relacionado con la inhibición del proceso de producción de la magnetita en estas condiciones.

Palabrasclave Tasa de corrosión. Difracción de rayos X. Acero. Espectroscopia Mössbauer. Iones cloruro y sulfato.

\section{INTRODUCTION}

In a previous study ${ }^{[1]}$ it was found that the corrosion rate, from low carbon steel, decreased when subjected to a certain combination of chloride and sulfate ion solutions. That work was based on measurements of the corrosion products by Mössbauer Spectroscopy (MS) at room temperature, the corrosion potential, and the corrosion rate obtained under different solutions of pollutants, chloride and sulfate ions. In the present work the corrosion products are further analyzed by X-ray diffraction (XRD).

Effects of the beneficial combined action of pollutants, on the corrosion rates, have been found in atmospheric rust formation and laboratory simulations ${ }^{[2-7]}$, and also the synergetic effect of pollutants to inhibit corrosion on different system has appeared in the literature ${ }^{[8 \text { and } 9]}$.

It is helpful to remember that the corrosion rate increases steadily, for low carbon steel, as the chloride concentration increases according to work by Flores-Merino ${ }^{[10]}$. In literature ${ }^{[1]}$ the time evolution of the rust under the combined effect of chloride and sulfate ions was studied, using an immersion-emersion test set up by Pourbaix ${ }^{[11]}$, simultating wet and dry periods, at intervals of 10 , 20 and $65 \mathrm{~d}$. The corrosion potential when the samples leave the solution was measured, the

${ }^{*}$ Instituto de Física. Universidad de Antioquia. A.A. 1226 Medellín (Colombia). Grupo de Corrosión y Protección. Departamento de Ingeniería de Materiales. Universidad de Antioquia. A.A.1226 Medellín (Colombia). 
composition of the rust formed for every period was analyzed by means of Mössbauer spectroscopy, and the corrosion rate was obtained by a gravimetric method.

The present work aims to shed some light to the mechanism leading to the inhibition of magnetite production at the particular conditions stated above by using the complementary information given by XRD an MS.

\section{EXPERIMENTAL PROCEDURE}

The experimental set up consisted in six vessels containing pollutant concentrations, of $\mathrm{SO}_{4}{ }^{2-}$ and $\mathrm{Cl}^{-}$ions, as shown in table I. The solutions $\mathrm{pH}$ was kept around $6.0 \pm 0.6$ during the experiment and were changed every other day to avoid contamination with corrosion products. The solutions were aerated continuously during the experiment.

The samples of AISI 1008 low carbon steel were $150 \times 30 \times 3 \mathrm{~mm}$. They rotated continuously over a period of about $41 \mathrm{~min}$, for $13 \mathrm{~min}$ the samples were immersed in the solution and the rest outside at a temperature around $45^{\circ} \mathrm{C}$ simulating the drying period. Four samples, from each Vessel, were removed at each period of 10,20 and $65 \mathrm{~d}$. During this time the corrosion potential was measured twice a day when the plaque entered and left the solution. Three specimens from each batch were used to measure the corrosion rate, by means of a gravimetric test, in accordance with the ISO norm 156/4 N 153. The corrosion rate is obtained from the expression:

$$
V_{\mathrm{CORR}}=\frac{10 \times m}{\mathrm{~A} \times \delta \times t}
$$

where $m$ is the mass lost in $\mathrm{mg}, \mathrm{A}$ is the area exposed to corrosion in $\mathrm{cm}^{2}, \delta$ is the material density in $\mathrm{g} / \mathrm{cm}^{3}$, and $t$ is the exposure time in days. The results are shown in table I.

The rust obtained was classified in two types, one which was loosely bound and fell down by hitting the sample with a hammer, the outer rust; and a second one which was scrapped from the surface, the inner rust. The other rust was analyzed by Mössbauer spectroscopy at room temperature. Samples from the $10 \mathrm{~d}$ batch did not produce any outer rust for this reason the inner one was prefered for the analysis.

X-ray spectra of the outer rust were taken using a Philips 2236/20 diffractometer, no sample was available for $10 \mathrm{~d}$ Vessel 4.

\section{RESULTS AND DISCUSSION}

Tables II and III show the results obtained from analysis of the X-ray diffraction spectra together with previous results ${ }^{[1]}$, for the relative amounts of the oxides, given by Mössbauer spectroscopy for Vessels 1, 3, 4, and 6 respectively. L, G, and M stand for lepidocrocite, goethite, and magnetite respectively; the numbers after the dash mean the Intensity taken from ICDD cards, A \% is the area percentage of each peak and 2 Theta are typical peak positions. Components different from these were not found in $\mathrm{X}$-ray spectra so both spectroscopies agree in this respect. XRD shows a low goethite area, in contrast to MS which shows a more substantial goethite contribution, but these apparent divergent results can be understood due to the small particle size distribution of this oxide which produces very broad lines in XRD resembling an amorphous-like system. In contrast MS shows the full relative amount of geothite split into a sextet, a magnetic component, and a doublet, a superparamagnetic component (spgoethite) unfortunately this doublet has similar

Table I. Chloride molar concentrations, chloride to sulfate ratios, and corresponding mean corrosion rate for each exposure period

Tabla l. Concentraciones molares de cloruros, razón de cloruros a sulfatos y tasa de corrosión en cada período

\begin{tabular}{lllllll}
\hline$\left[\mathrm{Cl}^{-}\right] \times 10^{-3} \mathrm{M}$ & 1.00 & 1.00 & 1.25 & 1.50 & 1.75 & 3.00 \\
{$\left[\mathrm{Cl}^{-}\right] /\left[\mathrm{SO}_{4}{ }^{2-}\right]$} & 0.080 & 0.100 & 0.125 & 0.150 & 0.175 & 0.150 \\
Vessel & 2 & 1 & 3 & 4 & 5 & 6 \\
Period (d) & & & Corrosion rate $(\mu \mathrm{m} / \mathrm{d})$ & & \\
10 & 1.38 & 1.28 & 1.44 & 0.56 & 1.11 & 1.11 \\
20 & 0.77 & 1.00 & 1.08 & 1.02 & 1.22 & 1.16 \\
65 & 0.32 & 0.38 & 1.34 & 0.61 & 0.89 & 1.35 \\
\hline
\end{tabular}


An X-ray diffraction study of corrosion products from low carbon steel A.L. MORALES

Table II. X-ray diffraction and Mössbauer spectroscopy results for Vessels 3 and $6 . \mathrm{L}=$ lepidocrocite, $G=$ goethite, $M=$ magnetite, Int. = intensity from ICCD cards, $A \%=$ relative area

Tabla II. Resultados de difracción de rayos $X$ y espectroscopia Mössbaver para los recipientes 3 y 6 . $L=$ lepidocrocita, $G=$ goethita, $M=$ magnetita, Int. = intensidad tomada de las tarjetas $I C C D, A \%=$ Área relativa

\begin{tabular}{|c|c|c|c|c|c|c|c|}
\hline \multirow{2}{*}{$\begin{array}{l}\text { Vessel } \\
\text { Time (d) }\end{array}$} & & \multicolumn{3}{|c|}{ Vessel 3} & \multicolumn{3}{|c|}{ Vessel 6} \\
\hline & & 10 & 20 & 65 & 10 & 20 & 65 \\
\hline Oxide-Int. & 2Theta & A \% & A \% & $A \%$ & A \% & A \% & A \% \\
\hline L-100 & 16.339 & 79.5 & 48.7 & 7.4 & 43.5 & 41.8 & 11.7 \\
\hline G-100 & 24.315 & 9.4 & 14.0 & 5.8 & & 20.6 & 10.6 \\
\hline L-90 & 31.466 & 74.1 & 80.3 & 7.3 & 59.3 & 57.0 & 12.0 \\
\hline$M-70(L-10)$ & 34.967 & 20.6 & 19.3 & 24.0 & 11.5 & 6.5 & 21.9 \\
\hline G-30 & 38.707 & 5.4 & 4.6 & 2.5 & & 4.0 & 5.7 \\
\hline$M-100(G-4)$ & 41.678 & 46.6 & 55.5 & 100.0 & 38.7 & 14.8 & 100.0 \\
\hline L-80 (G-16) & 42.345 & 100.0 & 100.0 & 14.3 & 100.0 & 100.0 & 28.0 \\
\hline \multicolumn{8}{|c|}{ Mössbauer } \\
\hline M & & 22.9 & 20.1 & 58.0 & 17.7 & 8.5 & 42.9 \\
\hline G & & 28.3 & 22.5 & 20.7 & 29.5 & 33.9 & 24.1 \\
\hline$G+L$ & & 48.8 & 57.4 & 21.3 & 52.8 & 57.5 & 34.2 \\
\hline
\end{tabular}

Table III. X-ray diffraction and Mössbauer spectroscopy results for Vessels 4 and 1. L = lepidocrocite, $G=$ goethite, $M=$ magnetite, Int. = intensity from ICCD cards, $A \%=$ relative area

Tabla III. Resultados de difracción de rayos $X$ y espectroscopia Mössbaver para los recipientes 4 y 1 . $L=$ lepidocrocita, $G=$ goethita, $M=$ magnetita, Int. = intensidad tomada de las tarjetas $I C C D, A \%=$ Área relativa

\begin{tabular}{|c|c|c|c|c|c|c|c|}
\hline \multirow{2}{*}{$\begin{array}{l}\text { Vessel } \\
\text { Time (d) }\end{array}$} & & \multicolumn{3}{|c|}{ Vessel 4} & \multicolumn{3}{|c|}{ Vessel 1} \\
\hline & & 10 & 20 & 65 & 10 & 20 & 65 \\
\hline Oxide-Int. & 2Theta & & $A \%$ & A \% & A \% & A \% & A \% \\
\hline L-100 & 16.282 & & 68.9 & 83.3 & 65.0 & 55.8 & 62.0 \\
\hline G-100 & 24.488 & & 5.5 & 13.0 & & 5.3 & 11.5 \\
\hline L-90 & 31.428 & & 84.7 & 100.0 & 96.5 & 80.1 & 87.5 \\
\hline M-70 (L-10) & 34.907 & & 11.8 & 7.9 & 19.5 & 6.8 & 15.1 \\
\hline $\mathrm{G}-30$ & 38.653 & & & 8.4 & 8.5 & 5.0 & 11.0 \\
\hline M-100 (G-4) & 41.487 & & 31.9 & 23.0 & 62.4 & 11.4 & 33.5 \\
\hline L-80 (G-16) & 42.315 & & 100.0 & 86.6 & 100.0 & 100.0 & 100.0 \\
\hline \multicolumn{8}{|c|}{ Mössbauer } \\
\hline$M$ & & 19.2 & 16.2 & 10.2 & 14.8 & 8.7 & 9.8 \\
\hline G & & 24.2 & 23.2 & 25.9 & 33.8 & 26.6 & 26.4 \\
\hline$G+L$ & & 56.6 & 60.6 & 63.9 & 51.4 & 64.6 & 63.8 \\
\hline
\end{tabular}

parameters as the lepidocrocite doublet and it is not possible to distinguish them at room temperature.

Two corrosion regimes can be distinguished in this study ${ }^{[1]}$, namely, one that goes up to $20 \mathrm{~d}$ of the experiment and the second one covers from 20 to $65 \mathrm{~d}$. During the first regime the dominating corrosion products are goethite and lepidocrocite in all vessels. In the second regime two different behaviors are found, i.e., in Vessels 1 and 4 goethite and lepidocrocite continues to dominate whereas in Vessels 3 and 6 magnetite dominates. These two regimes are corroborated in the behavior of the corrosion potential discussed ${ }^{[1]}$, where for the first $20 \mathrm{~d}$ of experiment the corrosion potential grows toward higher values with large oscillations and from 20-65 d it stabilizes growing toward higher and positive values for Vessels 1 and 4, but decreasing toward negative values for Vessels 3 and 6. This behavior is a fingerprint of the different corrosion routes developed in these vessels leading to significantly different rust compositions.

It was concluded ${ }^{[1]}$ that Vessel 4 was special due to its low corrosion rate when it was expected a higher rate due to the large chloride concentration. 
The hypothesis was that this low corrosion rate is promoted by a combined effect of the given sulfate and chloride concentrations since it is the only variable which differs from the other vessels. The actual reason why this beneficial effect is occurring is not fully understood yet. By monitoring the corrosion products at different times it is hoped to shed some light into the corrosion mechanism in this case.

The amounts of corrosion products during the first $20 \mathrm{~d}$ of the experiment agree with the literature on carbon steels, e.g., Leidheiser and Czako-Nagy ${ }^{[12]}$ found lepidocrocite and goethite as the main rust components in laboratory simulations and field experiments. The rust composition also agrees with the well known mechanisms of rust formation put forward by Stratmann and Hoffmann ${ }^{[13]}$, according to which the magnetite present comes from irreversible reduction of lepidocrocite while goethite is formed also from lepidocrocite during the drying cycle.

The protective properties of rust layers is related to the presence of the oxides in the form of small particles, mainly of goethite, as was found by Yamashita et al..$^{[14]}$ and Davalos et al. ${ }^{[15]}$ in weathering steels. In the present study it is found substantial amounts of small particle goethite, in Vessels 1 and 4, as seen in Mössbauer spectroscopy ${ }^{[1]}$ and XRD, this indicates the formation of a protective rust layer leading to low corrosion rates.

For Vessels 3 and 6 the chloride concentration dominates leading to a large magnetite content in the rust and large corrosion rates for the long range corrosion regime, while in Vessel 4 chloride concentration also dominates but with a lower corrosion rate. It has been conjecture that this behavior is due to a combined effect, at this particular concentrations, of both pollutants that produce large quantities of small particle goethite and consequently to the formation of a protective rust layer. What can be concluded from XRD and Mössbauer spectroscopy is that there occurs an enhanced transformation from Lepidocrocite to Magnetite in Vessels 3 and 6 while this transformation is inhibited in Vessel 4 for reasons not understood at present.

\section{CONCLUSIONS}

It is found from XRD, together with MS, that large quantities of small particle goethite are present leading to the formation of a protective rust layer which reduces the corrosion rate. The mechanism which produces the beneficial effect of sulfate and chloride ions is related to the inhibition of magnetite production from lepidocrocite. Further work to elucidate this mechanism should find better ways to find the amounts of corrosion products present combined with in situ MS and electrochemical analysis.

\section{Acknowledgments}

This work was partially supported by the Colombian Research Council, Colciencias. We thank Dr. Vandenbergue and Dr. Dauwe, Gent University, Belgium, for providing us with the Xray fitting program and also for allowing us to use their X-ray spectrometer. Thanks are given to Cheng Dong, Institute of Physics, China, for providing Powderx for X-ray analysis.

\section{REFERENCES}

[1] A.L. Morales, D. Cartagena, J.L. Rendón and A. Valencia, Physica Status Solidi (b) 220 (2000) 351356.

[2] G.V. Golovina, G.M. Floriantovich and I.A.M. Kolotyrkin, Zashch. Met. XV (1979).

[3] F. Corvo and Y. Leon, Rev. Iber. Corros. y Prot. XIX (1988) 291-298.

[4] A. Valencia, J. Arias and G. Villa, Proc. of the 5th Iberoamerican Congr. on Corrosion and Protection, Tenerife, Spain, 1995, pp. 91-94.

[5] A.L. Morales, D. Cartagena, J.L. Rendon, A. Valencia, C.A. Barrero and C. Dauwe, Hyp. Int. (C) 2 (1997) 143-148.

[6] B. Gaur, T.B. Singh and D.D.N. Singh, Corrosion 52 (1996) 154-160.

[7] T.J. Hakkarainen, Proc. of the $14^{\text {Th }}$ International Corrosion Congress, Cape Town, South Africa, 1999, pp. 202-205.

[8] Y. Feng, K.S. Sion, W.K. TeO, K.L. TAN and A.K. Hsieh, Corrosion 53 (1997) 546-550.

[9] J.P. Duthil, G. Mankowsky and A. Giusti, Corros. Sci. 38 (1996) 1839-1845.

[10] S. Flores-Merino, Ph.D. thesis, U. Complutense de Madrid, Spain, 1994.

[11] M. Pourbaix, Rapport Technique CEBELCOR RT 160, Bruxelles, 1969, p. 109.

[12] H. LeidHeiser and I. CZAKo-NAgY, Corros. Sci. 24 (1984) 569-577.

[13] M. Stratmann, and K. Hoffmann, Corros. Sci. 29 (1989) 1329-1352.

[14] M. Yamashita, H. Nagano, T. Misawa and H.E. TOWNSEND, ISIJ Int. 38 (1998) 285-290.

[15] J. Davalos, M. Gracia, J.F. Marco and J.R. Gancedo, Hyp. Int. 69 (1991) 871. 